\title{
УДОСКОНАЛЕННЯ ПРАВОВОГО РЕГУЛЮВАННЯ ТРАНСПЛАНТОЛОГІї У СВІТЛІ СВРОПЕЙСЬКИХ СТАНДАРТІВ
}

\begin{abstract}
БОГОМАЗОВА Ірина Олександрівна - кандидат юридичних наук, доцент кафедри медичного права, факультет післядипломної освіти Львівського національного медичного університету імені Данила Галицького
\end{abstract}

УДК 340.12:342.7

DOI 10.32782/LAW.2020.3.25

В статье обсуждается возможность введения презумпиии согласия на изгятие анатомических материалов после смерти человека. Поддаются анализу альтернативнъе способъ построения правил по умолчанию для урегулирования такой процедурьл. Обзор практики ЕСПЧ дает основания утверждать, что введение презумпиии согласия не противоречит Конвениии, но требует обеспечения гарантий для иленов семей умерших возразить против проведения этой прочедуры в отношении умершего. Введение презумпиии согласия позволит перераспределить удельный вес ответственности за проведение процедуры между государством, врачами и членами семьи умершего.

Ключевъге слова: трансплантачия, донорство, анатомические материаль, фетальные материальл.

\section{Постановка проблеми}

Можливість трансплантації органів, тканин та клітин людини зазнає особливої уваги з боку українських правників. Зазначена тема концентрує моральне, правове, психологічне й соціальне напруження, оскільки процедура пов'язана з ймовірною смертю пацієнта у разі відсутності змоги замінити нежиттєздатний орган, смертю людини, тіло якої може послугувати трансплантологічним матеріалом; загроза втрати фізичного здоров'я живого донора.

Правова інституціоналізація трансплантології потребує не лише медико-наукового обгрунтування, а й етичного осмислення dcix переваг у «невтомній боротьбі людства за максимальне продовження життя» та «очевидних складнощів, спричинених цією боротьбою» $[1$, с. 81$]$.

Закон України «Про застосування трансплантації анатомічних матеріалів людині» (далі - Закон) визначає трансплантацію як «спеціальний метод лікування, що полягає в пересадці анатомічного матеріалу людини від донора реципієнту і спрямований на відновлення здоров'я людини» [2]. Трансплантація? як спеціальний метод лікування, забезпечує додержання в Україні прав людини та захист людської гідності при застосуванні трансплантації та здійсненні іншої, пов'язаної з нею діяльності. Як відзначає Н. Крилова, ця процедура проводиться з метою порятунку життя, відновлення здоров'я, покращення якості життя» [3, с. 56], з чого випливають деякі обмеження для самої процедури, аби та була засобом забезпечення права людини на медичну допомогу, а не предметом торгівлі.

Думки науковців щодо доцільності впровадження «презумпції згоди» різняться. Зокрема, О. Капитова, О. Романовська, Г. Романовський вказують, що, «систематизувавши всі «за» $\mathrm{i}$ «проти», презумпція згоди на посмертне вилучення органів для трансплантації наглядно демонструє численну перевагу перших над другими. Можна сказати, що єдиним аргументом противників презумпції виступає необхідність захисту гідності особи і дотримання прав пацієнта, який $є$ потенційним донором. Аргументи ж на користь презумпції згоди більш різноманітні і багаточисельні - починаючи від суто організаційних 
проблем нестачі часу і закінчуючи завідомо невигідністю такого рішення для благої суспільної мети розвитку трансплантології» [4, с. 104].

Як зазначає I.Я. Сенюта у своєму аналізі трансплантаційного законодавства, говорити про його реформування ще зарано, адже Україна перебуває у непростих соціально-економічних умовах. Зокрема, спостерігається зростання кількості соціально незахищених верств населення, що може слугувати фактором для комерціалізації цієї сфери: «... [Т]іло людини та його частини не повинні бути джерелом отримання фінансової вигоди, що чітко передбачено у ст. 21 Конвенції про права людини і біомедицину. Побутує думка до того ж, що ментально й психологічно український народ не готовий до радикальних кроків. Має бути втілена поетапна зважена державна програма, яка спрямовуватиметься, зокрема, й на просвітництво, висвітлення позитивів цього методу лікування, що подекуди є єдиним способом врятування життя, зокрема дитини (ця проблема добре відома, зрозуміла лише людям, які зустрілись «обличчям» із хворобою, яку можна вилікувати саме завдяки трансплантації)» [5, с.7]. Авторка вважає, що зміни до трансплантаційного законодавства, зокрема, в аспекті трансформації презумпцій, $\epsilon$ передчасними й потребують додаткового обговорення, з чим доцільно погодитись.

Пропонований матеріал є продовженням саме такого обговорення і містить результати проведеного нами аналізу вітчизняного законодавства на предмет забезпечення прав людини при вилученні анатомічних матеріалів. Зокрема, буде продемонстровано, що з етичного боку немає необхідності отримувати чітко висловлену пряму згоду від майбутнього донора, або від членів його сім'ї чи близьких родичів. Презумпція згоди на вилучення анатомічного матеріалу, за впровадження якої вже багато років виступають медичні асоціації, громадські діячі та правники у сфері медичного права, не суперечить правам людини при правильній конфігурації прав і обов'язків учасників відповідного правовідношення.

\section{Умови трансплантації за національним законодавством}

Закон передбачає вичерпний перелік умов, за яких можливим є застосування тран- сплантації. Згідно зі ст. 13 Закону трансплантація застосовується виключно за наявності медичних показань і здійснюється відповідно до галузевих стандартів у сфері охорони здоров'я за згодою об'єктивно поінформованої дієздатної особи (реципієнта), за винятком випадків, передбачених цим же законом.

Наявність у пацієнта медичних показань для застосування трансплантації встановлює консиліум лікарів закладу охорони здоров'я, у якому пацієнт перебуває на лікуванні чи диспансерному обліку. Окрім того, Закон встановлює, що у разі якщо реципієнт не досяг 14-річного віку або визнаний в установленому законом порядку недієздатним, трансплантація застосовується за згодою об'єктивно поінформованих його батьків або інших законних представників. Стосовно реципієнтів віком від 14 років або визнаних в установленому законом порядку обмежено дієздатними трансплантація застосовується за згодою таких об'єктивно поінформованих осіб. Цей аспект процедури можна вважати традиційним, оскільки отримання відповідної згоди вимагає ст. 43 Закону України «Основи законодавства про охорону здоров'я» ${ }^{1}$.

Закон передбачає низку обмежень на донорство анатомічних матеріалів як при житті, так і після смерті людини, які, знову ж таки, пов'язані загалом із необхідністю забезпечити право на якісну медичну допомогу, з одного боку, та додатковими гарантіями для забезпечення прав людини вразливих груп ${ }^{2}$, 3 іншого. Принаймні частина 3 означених підстав зумовлена міркуваннями емпіричного досвіду, зокрема повідомляють про масові

\footnotetext{
1 Виняток 3 цього правила становлять випадки, коли реципієнт перебуває у невідкладному стані, що становить пряму та невідворотну загрозу його життю, медична допомога із застосуванням трансплантації надається без згоди реципієнта, його батьків або інших законних представників.

2 Зокрема, вилучення органів не застосовується до осіб, які утримуються у місцях відбування покарань та попереднього ув'язнення; $є$ іноземцями та особами без громадянства, які незаконно перебувають в Україні; страждають на тяжкі психічні розлади; мають захворювання, що можуть передатися реципієнту або зашкодити його здоров'ю, крім випадків наявності поінформованої згоди реципієнта; надали раніше орган або частину органа для трансплантації (крім гемопоетичних стовбурових клітин); $є$ вагітними.
} 


\section{Цивільне, підприсмницьке, господарське та трудове право}

вилучення анатомічних матеріалів у місцях позбавлення волі в КНР [6, с. 2542].

Прижиттєве донорство можливе у разі родинного або перехресного донорства та лише за наявності добровільної та усвідомленої згоди на донорство анатомічних матеріалів, наданої у письмовому вигляді. Згода на вилучення анатомічних матеріалів надається після надання особі лікарем об'єктивної та доступної інформації про можливість виникнення ускладнень для ії̈ здоров'я, а також про іiі права у зв'язку з донорством ${ }^{3}$.

Важливість гарантії стосовно надання повної та об’єктивної інформації донору і реципієнту щодо трансплантації органу, тканини чи іншого анатомічного матеріалу підкреслює Декларація про трансплантацію людських органів, прийнята 39-ю Всесвітньою медичною асамблеєю в жовтні 1987 року, а саме: «обов'язковим є якомога повніше обговорення пропонованої процедури 3 донором i реципієнтом або їх довіреними родичами або юридичними представниками. Аікар повинен бути об'єктивним при обговоренні процедури, при інформуванні і про відомий ризик, і можливі небезпеки, при пропозиції можливих альтернативних процедур. Аікар не повинен підтримувати очікування, які не виправдані обставинами. Інтерес лікаря до поглиблення наукових знань повинен завжди бути вторинним по відношенню до головного обов’язку лікаря перед пацієнтом. Завжди має бути отримано добровільну інформовану згоду» [7].

\section{Презумпція згоди вилучення фетальних матеріалів: національне законодавство і практика}

Европейського суду з прав мюдини

Презумпція як юридична конструкція використовується для розподілу прав і обов'язків учасників суспільних відносин за невизначеності юридичного факту, замінюючи останній собою.

Практика низки країн передбачає, що кожна особа, котра не залишила прижиттєвої

\footnotetext{
${ }^{3}$ У віком до 18 років, інформація про можливість виникнення ускладнень для іiї здоров'я, а також про іiі права у зв'язку з донорством також надається батькам цієї особи або іiї іншим законним представникам.
}

письмової незгоди на використання органів ії тіла для трансплантації, після іiї смерті може бути використана як донор для тих, хто цього потребує. Такий спосіб вирішення характерний для Франції, Австрії, Бельгії, Іспанії, Греції, Португалії тощо. Слабша форма цієї презумпції передбачає, що кожна дієздатна особа, котра досягла 18-річного віку, має право написати інформативну згоду стати донором органів, тканин чи анатомічного матеріалу після ії смерті. Така практика поширена в СІІА, Японії, Німеччині, Великобританії тощо. де, як правило, фіксація такої згоди вже міститься в медичній картці пацієнта.

Так само, згідно із частиною 1 статті 16 Закону, кожна повнолітня дієздатна особа має право надати письмову згоду або незгоду на вилучення анатомічних матеріалів 3 іï тіла для трансплантації та/або виготовлення біоімплантатів після визначення ії стану як незворотна смерть (смерть мозку або біологічна смерть) відповідно до закону (далі - згода або незгода на посмертне донорство). Відомості щодо наданих особою письмової згоди або незгоди на посмертне донорство, письмової заяви про відкликання наданої раніше такої згоди або незгоди вносяться в установленому порядку до Єдиної державної інформаційної системи трансплантації органів та тканин в установленому порядку до Єдиної державної інформаційної системи трансплантації органів та тканин.

Таким чином, законодавцем закріплено презумпцію незгоди з вилученням анатомічних матеріалів в донора-трупа. Це, певна річ, найбезпечніша i найобережніша позиція 3 точки зору відповідальності закладів охорони здоров'я (та опосередковано держави у випадку відсутності адекватного реагування на порушення прав людини в цій сфері), і в цьому ж, як видається, полягає вразливість такого ставлення законодавця до проблем трансплантології, адже первинною метою проведення процедури є людина та ії життя і здоров'я.

Втім, здається, законодавця тут можна зрозуміти, адже є повчальний досвід держав, які запровадили презумпцію згоди на фетальну трансплантацію і наразилися на скарги 3 боку членів сім’ї громадян, анатомічні матеріали в яких було вилучені без їхньої згоди. 
Так, згідно із законодавством Латвії 2004 р., будь-яка дієздатна особа мала право, в письмовому вигляді, дати згоду або висловити відмову на використання свого тіла після смерті $[8$, 9] - аналогічно як в Україні, і таке волевиявлення мало обов'язкову юридичну силу. Крім того, особа, яка бажала скористатися вищезазначеним правом, зобов'язана була звернутися до компетентних органів держави, відповідно до процедури, встановленої урядом, 3 тим, щоб зафіксувати своє волевиявлення в спеціальному реєстрі. За відсутності явно вираженої волі померлого анатомічні матеріали могли бути використані, якщо ніхто 3 найближчих родичів (дітей, батьків, братів або сестер, дружина) не заперечував проти такого використання. Посмертне донорство органів і тканин з метою трансплантації було можливим тільки в разі відсутності заперечень з боку донора, виражених за життя, або при відсутності заперечень 3 боку його найближчих родичів.

У справах Петрова проти Аатвії та Ельберте проти Аатвії ЄСП $\Lambda$ мав оцінити на відповідність Євроконвенції процедури вилучення анатомічних матеріалів у померлих членів сім'ї заявників [8, 9]. В обидвох випадках сім'ї померлих не були повідомлені про те, що лікарня вилучила анатомічні матеріали в їхніх загиблих родичів, а дізналися про це згодом в ході проведення розслідування у кримінальних справах. Згідно 3 позицією ЄСПл, такі дії лікувального закладу спричинили порушення права заявників на повагу до їхнього сімейного життя, що гарантоване ст. 8 Конвенції. Це відбулося, зокрема, через вади законодавства, а саме через те, що праву заявників бути поінформованими про намір вилучити анатомічні матеріали не відповідав обов'язок посадових осіб здійснити таке інформування. Абстрактне право бути поінформованим у зв'язку з абстрактним обов'язком поінформувати неодмінно суперечитиме розумінню прав людини Страсбурзьким судом як ефективних, а не теоретичних та ілюзорних [10].

Отже, згідно з практикою ЄСП закріплення презумпції згоди на посмертну трансплантацію не становить порушення права людини близьких родичів на повагу до їх сімейного життя - випадку, якщо їм надана реальна можливість заборонити вилучати анатомічні матеріали члена їхньої сім’ї після смерті.

\section{Висновки}

При розгляді можливості запровадження презумпції згоди в Закон України «Про застосування трансплантації анатомічних матеріалів людині» вважаємо за потрібне врахувати не лише ту обставину, що презумпція згоди може зумовити суспільний резонанс, що є супутником будь-яких змін як позитивних, так і негативних. Широкому загалу важливо зрозуміти, що конструкція презумпції згоди існує не тільки для забезпечення потреб людини, але і для розподілу відповідальності між учасниками правовідношення щодо вилучення та трансплантації анатомічних матеріалів. При цьому, члени сім'ї померлої людини в більшості випадків не заперечують проти вилучення, однак не згодні брати на себе всю повноту відповідальності. Відтак, правовідношення із вилучення анатомічних матеріалів повинно бути побудоване на засадах справедливого розподілу відповідальності між безпосередніми учасниками правовідношення та державою.

\section{Аітература}

1. Аболіна Т.Г., Нападиста В.Г., Рихліцька О. Д. та ін. Прикладна етика. Навчальний посібник / За наук. ред. Панченко В.I. К.: «Центр учбової літератури», 2012, 392 с.

2. Закон України «Про застосування трансплантації анатомічних матеріалів людині» // Відомості Верховної Ради (ВВР), 2018, № 28, ст.232

3. Крылова Н. Е. Уголовное право и биоэтика (уголовно-правовые проблемы применения современных биомедицинских технологий): дисс. ... д-ра юрид. наук: 12.00.08.. Москва, 2006. - 411 с.

4. Капитова Е.А. Правовое регулирование трансплантологии. Монография /Е.А. Капитова, О.В. Романовская, Г.Б. Романовский Г.Б.. - Москва: ООО «Проспект», 2016,144 c.

5. Сенюта І.Я. Трансформація презумпції незгоди у презумпцію згоди: ризики і переваги // Український медичний часопис, 2012, c. 7,8 . 


\section{АНОТАЦІЯ}

у статті обговорюеться можливість запровадження презумпчї згоди на вилучення анатомічних матеріалів після смерті людини. Піддаються аналізу альтернативні способи побудови правил за замовчуванням для врегулювання такої процедури. Огляд практики ЕСПЛ дає підстави стверджувати, що запровадження презумпиіи згоди не суперечить Конвениї, але потребує забезпечення гарантій для членів сімей померлих заперечити проти проведення иієї процедури щодо померлого. Запровадження презумпиї згоди дозволить перерозподілити питому вагу відповідальності за проведення процедури між державою, лікарями та членами сім'ї померлої особи.

Ключові слова: трансплантачія, донорство, анатомічні матеріали, фетальні матеріали.

6. Vasilenko M.D. Presumption of Consent in the ECHR Practice and Legal Systems: legal models for organ removal for transplantation / Mykola D Vasilenko, Anastasiia O Zaporozhchenko, Borys A Perezhniak // Wiad Lek. 2019;72(12 cz 2), Pp. 2541-2546/

7. Декларація стосовно трансплантації людських органів, прийнята 39-ю Всесвітньою медичною асамблеєю 30.10 .1987 р. : [URL: https://zakon.rada.gov.ua/laws/ show/995_330\#Text]

8. Judgement of 24 June 2014 in the case of Petrova v. Latvia http://hudoc.echr.coe.int/ eng?i=001-144997]

9. Judgement of 13 January 2015 in the case of Elberte v. Latvia : [URL: http://hudoc. echr.coe.int/rus?i=001-150234]

10. Judgement of 28 May 2002 in the case of Stafford v. the United Kingdom : [URL: http:// hudoc.echr.coe.int/eng?i=001-60486]

\section{ON IMPROVEMENT OF THE LEGAL REGULATION OF TRANSPLANTOLOGY IN UKRAINE ACCORDING TO THE EUROPEAN STANDARDS}

The article discusses the possibility of introducing the presumption of consent to the removal of anatomical materials after death. Under the legislation of a number of countries any person who has not given his or her lifelong written consent to the use of his or her organs for transplantation may, after his or her death, be used as a donor for those in need. This solution is typical for France, Austria, Belgium, Spain, Greece, Portugal, etc. The weaker form of this presumption is that every able-bodied person who has reached the age of 18 has the right to write an informative consent to become a donor of organs, tissues or anatomical material after his death. This practice is widespread in the United States, Japan, Germany, Great Britain, etc. where, as a rule, the fixation of such consent is already contained in the patient's medical card.

According to ECtHR practice, enshrining the presumption of consent to a post-mortem transplant does not constitute a violation of the human right of close relatives to respect for their family life, provided that they have a real opportunity to prohibit the removal of their family members' anatomical materials after death.

Under the Ukrainian legislation, the disagreement with the removal of anatomical materials from the donor corpse is presumed. This is, of course, the safest and, perhaps, most cautious position in terms of the responsibility of health care facilities (and, indirectly, of the state in the absence of an adequate response to human rights violations in this area), and this seems to be the vulnerability of the legislator's attitude to problems of transplantation, because the primary purpose of the procedure is a person and his life and health.

Alternative ways of constructing default rules to handle such a procedure are analyzed. The review of the case law of the ECtHR enables to suggest that the adoption of the consent default rule is not contrary to the Convention but requires the provision of guarantees for family members of the deceased to object to this procedure in relation to the deceased. The introduction of the presumption of consent will redistribute the share of responsibility for the procedure between the state, doctors and family members of the deceased.

Key words: transplantation, donation, anatomical materials, fetal materials. 